\title{
CDS Primleri ile Ülke Kredi Riski Arasındaki ilișkinin Değerlendirilmesi; Türkiye Örneği
}

Esra N. KILCI ${ }^{1}$

Makale Geliș Tarihi: 09.03.2017

Makale Kabul Tarihi: 30.08.2017

\section{Öz}

Uluslararası yatırımcıların bir ülkeye doğrudan yatırım ve portföy yatırımları șeklinde yatırım yapmak konusundaki karar süreçlerinde, ülke kredi riskinin doğru bir șekilde değerlendirilmesi büyük önem tașımaktadır. Ülke kredi riskinin ölçülmesinde ve uluslararası yatırımcıların ülkeye yönelik risk algısının değerlendirilmesinde ise, büyük ölçüde, CDS primlerinden yararlanılmaktadır. Bu çalıșmada, ülkemiz açısından, ülke kredi riskinin artmasına yol açan makroekonomik değișkenler ve finansal değișkenler ile ülke CDS primleri arasındaki ilișki, ekonometrik uygulama aracılığıyla analiz edilmiș ve değișkenler arasındaki koentegrasyon test edilmiștir.

Anahtar Kelimeler: CDS Primleri, Ülke Kredi Riski, Johansen Koentegrasyon Testi

\section{An Assessment of the Relationship between CDS Spreads and Sovereign Credit Risk; Turkey Case}

\section{Abstract}

It is essential that sovereign credit risk is adequately evaluated in the decision making process of international investors in the form of foreign direct investment and portfolio investments. CDS

1 Dr., Trakya Üniversitesi, Uygulamalı Bilimler Yüksekokulu, Bankacılık ve Sigortacılık Bölümü, esra.kilci@gmail.com, , orcid.org/0000-0002-2239-4560. 
spreads are significantly used in measuring the sovereign credit risk and evaluating the risk appetite of foreign investors against the country. In this study, the relationship between macroeconomic and financial indicators which lead to increase in sovereign credit risk of Turkey and CDS spreads is analyzed with the help of an econometric application and tested that the variables are cointegrated or not.

Keywords: CDS spreads, Sovereign Credit Risk, Johansen Cointegration Test

\section{GíRiș}

Ülke kredi riskinin ölçülmesinde ve özellikle uluslararası yatırımcıların ülkeye yönelik risk algısının değerlendirilmesinde CDS$^{2}$ (Kredi Temerrüt Swapları) primleri belirgin biçimde dikkate alınmaktadır. Uluslararası yatıımcıların bir ülkeye hem doğrudan yatırımlar hem porfföy yatırımları șeklinde yatırım yapmak konusundaki karar süreçlerinde ülke kredi riskinin doğru ve uygun bir șekilde değerlendirilmesi büyük önem tașımaktadır. Örneğin, ülke içinde yașanılan ekonomik ve finansal göstergelerdeki bozulmayı takiben, ya da politik bir istikrarsızlığın ardından, ülke kredi riskindeki bir artıș, risk priminin artmasına yol açarak, uluslararası yatırımcıların hem tahvil-bono hem de hisse senedi piyasalarında çıkıs, yönünde hareket etmesine ve piyasalarda likidite problemlerinin artmasına neden olmaktadır. Ülke kredi riski, bir ülkenin ekonomik ve finansal performansını yansıtmasının ve bir ülkenin ekonomik ve finansal șoklara karșı dayanıklılı̆ının anlamlı bir ölçüsü olmasının sonucunda, dıș borçlanmalarda ülkenin karșılașacağı kaynak maliyetlerini direkt olarak etkilemektedir.

CDS primlerindeki değișim, bir ülkedeki ekonomik birimlerin kredi maliyetlerindeki gelișmeleri açık bir șekilde yansıtmaktadır ve bu durum, reel ekonominin performansına ilișkin önemli bir gösterge teșkil etmektedir. Ülkenin kredi risk primi ile ülkede faaliyet gösteren reel ve finansal tüm kurumların risk primi ve dolayısıyla fi-

2 Çalıșmanın ilerleyen kısmında, sadece CDS kavramı kullanılacaktır. 
nansman maliyetleri arasında kuvvetli bir etkileșim bulunduğu için, CDS fiyatlamalarında altta yatan dinamikleri ve CDS primlerinde değișimlere yol açan faktörleri doğru teșhis etmek, finansal istikrar açısından büyük önem tașımaktadır.

Bu çalıșmada, Türkiye 5 yıllık CDS primleri ile ülke kredi riskinde değișime yol açacağı düșünülen makroekonomik ve finansal değișkenler arasındaki ilișki incelenmeye çalıșılmıștır. Dolayısıyla, Türk bankacılık sektöründe takipteki krediler ve sermaye yeterliliği ile BIST 30 gibi finansal göstergelerin yanı sıra, büyüme, ișsizlik, enflasyon, cari açık ve reel kurdaki değerlenme gibi makroekonomik göstergeler ve CDS primleri arasındaki koentegrasyon, ekonometrik uygulama yardımıyla analiz edilmiștir. Çalıșmada, 2010-2016 dönemine ilișkin aylık veriler analize dahil edilmiștir. Verilerin toplanmasında, TÜIK, TCMB, HM veri tabanları ve Bloomberg'ten yararlanılmıștır.

\subsection{Tanımsal Olarak CDS}

CDS en basit haliyle, bir iflas halinin ortaya çıkması durumunda, elinde bulunduran kișiye söz konusu tahvil-bonoyu nominal değeri üzerinden satabilme olanağı veren finansal bir enstrümandır ve bu kredi türevi enstrüman aslında, bir temerrüt durumu yașanması halinde CDS alıcısını korumayı amaçlayan bir sigortadır. CDS alıcısı, satan tarafa, CDS'in ömrü boyunca ya da bir kredi durumu olușuncaya kadar periyodik ödemeler yapmayı kabul etmektedir. Anaparayı temsil eden tutarın yüzdesi olarak yıllık ödenen primler, CDS spreadi olarak adlandırılmaktadır. Șirketler ve ülkeler CDS sözleșmelerine konu olabilmektedir. Ülke CDS'lerinde altta yatan varlık ülke tahvil-bonolarıdır ve bu tür CDS'lerin spreadleri, incelenen ülkenin kredibilitesine ilișkin indikatörler olarak kullanılabilmektedir. Ülke CDS'lerinde, bir ülkenin finansal durumuna ilișkin her negatif ve pozitif bilgi, CDS marjına yansımakta; negatif bilgiler CDS primlerini arttırırken, pozitif bilgiler söz konusu primleri azaltmaktadır. Piyasadaki likidite arttıkça, bu hareketler daha algılanabilir hale gelmektedir (Kliber, 2011).

IMF, Küresel Finansal İstikrar Raporu'nda (s. 2), bir ülkenin kredi riskinin, global finansal istikrar üzerinde, finansal ve makro- 
ekonomik riskler ile gelișmekte olan ülkelerin risklerinden ziyade çok daha büyük bir etkiye sahip olduğu belirtilmektedir. Ülke kredi riskinin finansal sisteme vereceği zararın büyüklüğü nedeniyle, bir ülkenin kredi riskinin doğru ölçülmesi ve altta yatan determinantların doğru teșhis edilmesi son derece önemlidir (Wallison, 2009).

CDS ișlemi, borç veren taraflar açısından bir ülkenin iflas riskine karșı bir sigorta olarak düșünülmektedir. Bu sigortanın fiyatı, korumayı satan tarafa karșı korumayı satın alan tarafın sözleșme dönemi boyunca ödenen miktardır ve sigorta edilen nominal değerin oranı CDS marjı olarak ifade edilmektedir. CDS piyasasında yașanan muazzam gelișmenin bir sonucu olarak, kotasyonlar, borç alan tarafın risk priminin güncel değerine ilișkin en doğru resmi sunmaktadır. Ülkenin kredi risk primi ülkedeki diğer kurumların risk primini ve dolayısıyla finansman maliyetlerini etkilediği için, CDS fiyatlamalarında altta yatan dinamikleri doğru teșhis etmek finansal istikrar açısından büyük önem tașımaktadır. CDS marjlarındaki değișim, bir ülkedeki devlet, kurumlar ve hane halkları gibi birimlerin ekonomik kredi marjlarındaki gelișmeleri açık bir șekilde yansıtmaktadır ve bu durum, reel ekonominin performansına ilișkin önemli bir gösterge olarak kabul edilmektedir. Aynı zamanda, en azından kısa dönemde CDS marjlarının büyük ölçüde uluslararası gelișmeler tarafından belirlenmesi, ekonomik döngü içerisinde dalgalanmaların aktarılması sürecinde global finansal sistemin ne kadar önemli bir rol oynadığını göstermektedir (Kisgergely, 2009).

Gelișmekte olan ülke borçları üzerine düzenlenen CDS sözleșmeleri aktif bir șekilde ișlem görmektedir. Kredi riskinin ölçülmesinde ülke CDS verilerinin kullanılmasının önemli bir avantajı, ülke kredi swap piyasasının ilgili ülkenin tahvil piyasasına göre çoğu zaman çok daha likit olmasıdır ve dolayısıyla, ülke CDS'leri kredi spreadleri konusunda daha doğru tahminler sağlayabilmektedir (Adam; 2013).

CDS kotasyonlarındaki büyük hacimli risk primi değișiklikleri, piyasa beklentilerinde farklı yorumlara yol açabilmektedir. Özellikle, kredi riski yüksek enstrümanlara yönelik azalan iștah, altta yatan varlıklarda gelecekte yașanabilecek temerrütlere ilișkin 
artan beklentilerden ziyade, piyasa algısında farklı bir sinyale ișaret edebilmektedir. Dolayısıyla, kriz döneminde olușan yüksek risk primleri, kısmen azalan risk iștahı ve piyasa likiditesi nedeniyle olușabileceği gibi, borcun anapara kayıplarından ziyade, kredi not indirimlerinin artmasına ilișkin kaygılar nedeniyle de meydana gelebilmektedir (Fontana ve Scheicher, 2010).

\section{2. Ülke CDS'lerinin Öneminin Artmasına Yol Açan Gelișmeler}

CDS'ler üzerine yapılan çalıșmalar, ülke kredi riskinin daha iyi anlașılabilmesi açısından önemli ipuçları sağlamakta ve literatürde çalıșılan tahviller ve swaplar gibi geleneksel enstrümanlara göre, kredi riskinin farklı bir açıdan değerlendirebilmesine olanak sağlamaktadır. Aslında geçmiși 90'lı yıllara uzanan CDS'ler, kredi riskinden korunmak amacıyla finansal piyasalarda yoğun bir șekilde kullanılmaktadır ve ișlem gören referans varlıkların sayısı artıkça, piyasadaki likidite ve çeșitlilik de giderek artmaktadır (Cossin ve Jung, 2005).

CDS'lerin diğer kredi riski ölçütlerine göre en büyük avanta¡ı, primlerin çok düzenli bir șekilde, günlük bazda ayarlanması ve güncel piyasa koșullarını yansıtmasıdır. Spreadler günlük olarak revize edildiği ve söz konusu CDS sözleșmesine olan arz ve talebi yansıttığı için, piyasadaki her yeni durum, çok hızlı bir șekilde CDS primlerine yansımaktadır (Hull, 2008).

2008 yılında șiddetini arttıran global finansal krize kadar, ülke kredi notları, bir ülkenin kredi riskinin ölçülebilmesi amacıyla en çok bașvurulan göstergeydi. Kredi derecelendirme kurulușlarının krizi öngörmek konusunda yetersiz kaldığı yönündeki eleștiriler, ülke kredi riskinin ölçülmesine yönelik ve piyasanın en güncel durumunu gösteren ve değișen koșullara hızlı bir șekilde adapte olabilen farklı göstergelere olan talebi artırmıștır.

2007 yılı üçüncü çeyreğinden itibaren, kredi piyasaları, kredi riskinin fiyatlandırılması konusunda çok ilginç ve önemli bir süreç yașamaktadır. Söz konusu kredi krizi, birçok așamadan geçmiș ve birçok sektörü etkilemiștir. Yeniden değerleme süreci, esasen, $A B D$ konut piyasasında bașlamıș olup, birçok șirketi ve 
bankayı etkileyerek, kredi risklerinin büyük ölçüde yeniden değerlenmesi sürecini beraberinde getirmiștir. Finansal piyasalarda yașanan șiddetli türbülans, Lehman Brothers'ın iflas edișiyle çok șiddetli bir hale gelmiștir. Akabinde, finansal stres altındaki birçok banka sistemik riski yatıștırmak ve olumsuz makroekonomik birtakım sonuçlardan kaçınabilmek için kamulașıııılmıștır. Özellikle Eylül 2008'den beri, ülke borç piyasaları artan bir öneme sahip olmuștur. Global finansal krizden önce, kredi piyasalarındaki ișlemler, kurumsal kredi riski ve seküritizasyon araçları gibi özel sektör enstrümanlarına yoğunlașmıșken, 2008 son çeyreğinde Lehman Brothers'ın iflası, gelișmekte olan ülke devlet borçlarının yeniden değerlendirilmesi ve ele alınması sürecini de beraberinde getirmiștir. Bu durumun yașanmasında, iflas riski yüksek finansal kurumlara özellikle bankalara sağlanan yaygın ve geniș ölçekli devlet destekleri ve diğer destek önlemlerinin, bütçe açıklarını arttırmasının payı büyüktür (Fontana ve Scheicher, 2010).

Calıșmalar, ülke CDS spreadlerinin önemli bir kısmının yatırımcıların risk iștahı ve global ekonomik göstergeler gibi genel faktörlerle açıklandığına ișaret etmektedir. Bir ülkenin kredibilitesindeki artıș, sermaye olanaklarını artırmakta, söz konusu ülkelerin finansal sıkıntıları azalmakta ve dolayısıyla borçları üzerine yazılan CDS primlerinin azalmasıyla sonuçlanmaktadır. Ayrıca, bir ülkenin kredi kalitesi iyileștikçe, piyasalar açısından cazibesi artmakta; bu durum diğer ülkelerin sermaye akımlarını etkileyerek, CDS primlerinde hareketlere neden olabilmektedir (Ismailescu ve Kazemi, 2010).

Bir kurumun aksine, temerrüdün gerçekleșmesi durumunda, bir ülkenin varlığını sonlandırması mümkün görünmediği için, kredinin ödenememesi hali yani ülke kredi riskinin realize olması durumu, çoğu zaman yeniden yapılandırma veya dıș borçların tanınmaması șeklinde gerçekleșmektedir (Pan ve Singleton, 2008). Ülke riski esas olarak, bir ülkenin karșı karșıya kaldığı ekonomik, finansal ve politik tüm risklerin bir kompozisyonudur (Beers ve Cavanaugh, 2008). Bu noktada, CDS primlerindeki değișimler bize, ülke riskinin ne yönde hareket ettiği ile ilgili önemli ipuçları sağlamaktadır. 
Basitleștirilmiș arbitraj perspektifine göre, referans varlı̆ı̆ın CDS spreadi, aynı varlığın kredi spreadine eșit olmalıdır. Dolayısıyla, referans varlık olarak bir ülkenin CDS spreadlerinin, gösterge risksiz devlet tahvili veya bonosunun oranı çıkartıldıktan sonra, ülkenin borçlanabildiği faiz oranına eșit olması beklenmektedir ve yüksek CDS spreadleri, yüksek borçlanma oranlarına ișaret etmektedir. 2010 yılında, Euro Bölgesi'nde yașanan borç krizinde finansal açıdan ciddi anlamda stres yașayan Portekiz, İrlanda, İtalya, Yunanistan ve İspanya gibi ülkelerin karșı karșıya kaldığı finansal sıkıntılar, yüksek CDS primlerine yansımıș ve borçlanma oranlarında șiddetli yukarı hareketlere neden olmuștur (Brandorf ve Holmberg, 2010).

\subsection{Literatür Araștırması}

Literatürde, ülke CDS piyasalarının ve CDS primleri ile ülke kredi riski arasındaki ilișkinin incelendiği çalıșmaların özellikle 2008 yılından sonra hız kazandığı görülméktedir. Özellikle kredi derecelendirme kurulușları tarafından verilen notların, gerek 2008 'de hızlanan küresel finansal kriz gerek 2010'da Avrupa'da bașlayan borç krizi döneminde anlamını kaybetmesi ve finansal piyasalarda ülke ve șirketlerin performansını daha doğru yansıtabilecek daha anlamlı ölçütlere olan ihtiyaç, bu sürece çok olumlu katkı yapmıșıır. Așağıda, CDS primleri ile ülke kredi riski arasındaki ilișkinin incelendiği çalıșmalara kısaca yer verilmiștir.

Pan ve Singleton 2008 yılında yaptıkları çalıșmada, farklı jeopolitik karakteristiklere ve farklı kredi notlarına sahip olan Meksika, Türkiye ve Kore'nin CDS primlerini incelemișler ve CDS spreadlerịndeki değișimde etkili olan faktörleri tespit etmeye çalıșmıșlardır. Ülkeye özgü ve bölgesel ekonomik risklerin yanı sıra, yatırımcıların risk iștahının belirgin hale geldiğine ișaret etmișlerdir.

Remolona ve diğerleri 2008 yılında yaptıkları çalıșmada; 24 ülkenin 01.2002-05.2006 dönemine ait aylık CDS primleri ve ülke riski üzerinde etkisi olduğu düșünülen faktörler arasındaki ilișkiyi regresyon analiziyle incelemișler ve enflasyon oranının, VIX (Volatilite Endeksi) endeksi ve RTI gibi risk toleransını gösteren endekslerin ülke riski ve risk primi üzerinde etkili olduğu sonucuna ulașmıșlardır. 
Tang ve Yan 2009 yılında yaptıkları çalıșmada, makroekonomik göstergelerdeki değișimlerin ülke CDS primleri üzerindeki etkisini ölçmeye çalıșmıș ve GSYiH'daki büyüme ile CDS primleri arasında negatif bir yönlü ilișki olduğunu tespit etmișler; aynı zamanda, yatırımcı risk iștahının yükseldiği ve sistematik riskin düșük olduğu dönemlerde CDS primlerinin düștüğüne ișaret etmișlerdir.

Brandorf ve Holmberg 2010 yilında yaptıkları çalıșmada, İtalya, Yunanistan, İrlanda, Portekiz ve İspanya'ya ait CDS primlerinin 03.2004-09.2009 dönemindeki değerleri ile GSYiH'daki değișim, brüt borç stoku, ișsizlik ve enflasyon oranı gibi makroekonomik göstergeler arasındaki ilișkiyi regresyon analiziyle incelemișler ve kamu borcu, ișsizlik ve enflasyon oranı ile CDS primlerindeki değișim arasındaki ilișkiyi tespit etmișlerdir.

Fontana ve Scheicher 2010 yılında yaptıkları çalıșmada, Euro-Bölgesi'ndeki 10 ülkenin 01.2006-09.2008 dönemindeki haftalık CDS primleri ve risksiz faiz oranı, yatırımcıların risk algısı, dıș borç ve iTraxx endeksi arasındaki ilișkileri regresyon analizi yardımıyla incelemișler ve yatırımcı risk iștahındaki azalmanın CDS primlerinde artıșa neden olduğu sonucuna ulașmıșlardır.

Plank 2010 yılında yaptığı çalıșmada, Türkiye, Çek Cumhuriyeti, Rusya, Polonya, Romanya ve Macaristan'ın içinde bulunduğu gelișmekte olan ülkelere ait 5 yıl vadeli CDS primlerinin 01.2001-12.2009 periyodundaki değerlerini incelemiș ve olușturdukları modelde CDS primleri ile ülkelerin dıș borç ödeme güçleri arasında yüksek bir korelasyon olduğunu tespit etmiștir.

Longstaff ve diğerleri 2011 yılında yaptıkları çalıșmada, 10.2000-01.2010 periyodu için, Romanya, Meksika, Șili, Kore, Malezya ve Japonya gibi gelișmekte olan ve gelișmiș ülkelere ait CDS verilerini kullanarak, ülke kredi riskini analiz etmișler ve ülke kredi riskinin ağırlıklı olarak global faktörlerle ilișkilendirilebileceği sonucuna ulașmıșlardır. Çalıșma sonuçları, ülke CDS primlerinin, lokal ekonomik göstergelerden ziyade, $A B D$ hisse senedi piyasası ve yüksek getiriși piyasalarla ve aynı zamanda, VIX endeksiyle ifade edilen volatilite risk primiyle çok daha yakın ilișkide olduğunu göstermiștir. 
Sand 2012 yılında yaptığı çalıșmada, Euro-Bölgesi'ndeki 16 ülkeye ait 5 yıl vadeli CDS primlerinin 12.2007-03.2011 dönemindeki değerleri ile cari açık, risksiz faiz oranı, borcun/ GSYIH'ya oranı, reel döviz kuru, hane halkı borcu/GSYIH'ya oranı, risk iștahı ve enflasyon oranı gibi değișkenler arasındaki ilișkiyi regresyon analizi ve olay çalıșması yöntemiyle incelemișler ve değișkenler ile CDS primleri arasında pozitif ve negatif ilișkiler tespit etmișlerdir. Örneğin, cari açık ile CDS, risksiz faiz oranı, reel döviz kuru ve risk iștahı ile CDS primleri arasında negatif bir ilișki varken, borç/GSYiH oranı ve enflasyon oranı ile CDS primleri arasında pozitif bir ilișki tespit edilmiștir.

Türkiye'de de CDS primleri üzerine çeșitli araștırmalar yapılmıștır. Koy, 2015 yılında yaptığı çalıșmada CDS ve Euro-tahvil primleri arasındaki ilișkinin Avrupa Borç Krizi'nin bașlangıç dönemini de içine alan Ocak 2009-Kasım 2012 döneminde ne șekilde gerçekleștiğini araștırmıștır. Bu doğrultuda, seçilmiș sekiz ülkeye ait CDS primleri ile Euro-tahvil primleri arasındaki ilișki, birim kök testi ve Granger nedensellik analizi ile incelenmiștir. Bulunan sonuçlar Fransa ve İtalya CDS primlerinin tahvil primlerine yön verdiğine dair kanıtlar sunmaktadır.

Akkaya, 2017 yılında yaptığı çalıșmada, Türk tahvillerinin CDS primlerini etkileyen içsel faktörleri Ocak 2008-Mart 2016 dönemi için incelemiș; altın fiyatları, BIST getiri endeksi, ihracatın ithalatı karșılama oranı ile Türkiye 5 yıl vadeli ABD doları cinsinden tahvillerin CDS primleri arasında nedensellik tespit etmiștir.

\subsection{Data ve Metodoloji}

Özellikle 2008-09 Küresel Finansal Kriz döneminde, S\&P, Fitch ve Moody's gibi popüler uluslararası derecelendirme kurulușlarının kredi notlarıyla ilgili birtakım soru ișaretleri ortaya çıktığı için, CDS primi, son yıllarda ülke kredi riskinin ölçülmesinde en çok yararlanılan ölçütlerden biri haline gelmiștir. Ülke kredi riskinin yukarıda belirttiğim üzere, finansal, makroekonomik ve politik risk unsurlarının bir bileșimi olduğu düșüncesinden hareketle, söz konusu risk unsurları ile CDS primleri arasındaki ilișki ölçülmeye çalıșılmıștır. Örneğin, enflasyon, ișsizlik oranı ve cari ișlemler den- 
gesi açığı arttıkça CDS primlerinin artacağı düșünülürken, reel kurda ulusal para aleyhine yașanacak bir değerlenme sürecinin de, ülkenin döviz cinsinden yükümlülüklerinin ulusal para cinsinden karșılığını artıracağı için, yine CDS primleri ile pozitif bir korelasyona sahip olacağı beklenmektedir. Aynı zamanda, bankacılık sektöründe takipteki kredilerdeki artıș ile CDS primleri arasında pozitif korelasyon olacağı düșünülmektedir. Özellikle finansal volatilitenin yüksek olduğu dönemlerde bu değișkenler ile CDS primleri arasında belirgin bir ilișkinin olduğu belirtilmektedir.

Bu çalıșmada, ekonomik ve finansal risk unsurları ile Türkiye CDS primleri arasındaki ilișki analiz edilmeye çalıșılmaktadır. Bu doğrultuda, makroekonomik göstergelerden enflasyon, ișsizlik, büyüme oranı, reel efektif döviz kuru ve cari açık gibi değișkenler; finansal göstergelerden bankacılık sektörü takipteki krediler artıș oranı, sermaye yeterlilik oranı gibi değișkenler analize dahil edilmiștir. İlgili verilerin 2010-2016 yılına ilișkin aylık değerleri ve 5 yıl vadeli CDS primlerinin söz konusu döneme ilișkin ay sonu değerleri dikkate alınarak, Engle-Granger ve Johansen Koentegrasyon Testleri uygulanmıștır.

Veriler TCMB, TÜIK, HM veri tabanları ve Bloomberg'den yararlanılarak toplanmıș olup; Türkiye 5 yıllık CDS primleri analizde bağımlı değișken olarak kullanılmıștır. 1 ve 10 yıllık vadeler arasında en çok kullanılan vadenin 5 yıl olması nedeniyle bu șekilde hareket edilmiștir (Fontana and Scheicher, 2010, s. 8).

Makroekonomik ve finansal değișkenlerin belirlenmesinde așağıda belirteceğim gerekçeler etkili olmuștur. Örneğin, cari açığın yükselmesi, ülkelerin sermaye akımlarına olan bağımlılığını arttırmakta, dıș borçlanma ihtiyacının artması veya borcun sürdürülebilirliği konusundaki endișelerin artması, ülke kredi riskinin artmasına ve dolayısıyla CDS primlerinin artmasına yol açmaktadır. Hedeflenen enflasyon oranındaki artıșın, finansal istikrara zarar vereceği düșüncesinden hareketle, yüksek enflasyon oranlarının CDS primlerini artıracağı beklenmektedir. Diğer yandan, ekonomik büyümenin arttırılması ülkenin kredi riskini azaltacağı için CDS primlerinin așağı yönlü hareket etmesine yol açacaktır. Reel kurda ulusal para aleyhine yașanacak değerlenme, belirsizliği art- 
tırmakta, yatırımları ve ekonomik aktiviteyi olumsuz etkilemekte ve risk priminin artmasına yol açmaktadır. Ayrıca, döviz cinsinden yükümlülüklerin değerinin artması ülke kredi riskinin artmasına yol açacağından, CDS primleri ile kurda yașanan değerlenme arasında pozitif bir ilișki olması beklenmektedir. Bankacılık sektöründe takipteki kredilerin oranının artması ve sermaye yeterliliğinin azalması, finansal sektörle ilgili bozulmayı yansıtacağından, CDS primleri ile sözkonusu değișkenler arasında negatif bir korelasyon olacağı düșünülmektedir.

Hipotezim yukarıdaki açıklayıcı değișkenler ile CDS primleri arasında uzun dönemli bir ilișki ve koentegrasyon olduğudur. Așağıda, açıklayıcı değișkenler ve CDS primleri arasındaki ilișkinin tespit edilebilmesi amacıyla, öncelikle Engle-Granger Koentegrasyon ve akabinde Johansen Koentegrasyon Testleri yapılmaktadır.

\subsection{Ekonometrik Uygulama}

Öncelikle, bağımlı değișken ve bağımsız değișkenlerden olușan modeli olușturduktan sonra, tüm değișkenlerin durağanlıklarının test edilmesi amacıyla, Augmented Dickey Fuller Test uygulanmıșıır. Birimkök test sonuçlarına göre, I(1) düzeyde durağan halde olan seriler söz konusudur. Bağımlı değișkenimiz, TR 5 yıllık CDS primleridir. Test sonuçları așağıdaki tabloda yer almaktadır.

Tablo 1: ADF Test Sonuçları

\begin{tabular}{|l|c|c|c|c|}
\hline \multicolumn{5}{|c|}{ Makroekonomik ve Finansal Değișkenler için Birim-kök Testi (ADF) Sonuçları } \\
\hline Seriler & $\begin{array}{c}\mathbf{I}(\mathbf{0}) \\
\text {-istatistiği }\end{array}$ & $\begin{array}{c}\mathbf{I}(\mathbf{0}) \\
\text { Olasılık }\end{array}$ & $\begin{array}{c}\mathbf{I}(\mathbf{1}) \\
\text { t-istatistiği }\end{array}$ & $\begin{array}{c}\mathbf{I}(\mathbf{1}) \\
\text { Olasılık }\end{array}$ \\
\hline TR 5 Yıllık CDS Primleri & -3.027377 & 0.1312 & -10.10123 & 0.0000 \\
\hline Büyüme Oranı & -2.359881 & 0.3975 & -9.072345 & 0.0000 \\
\hline İșsizlik Oranı & -3.392902 & 0.0595 & -7.053291 & 0.0000 \\
\hline TÜFE Oranı & -2.491172 & 0.3317 & -7.293323 & 0.0000 \\
\hline Cari Açık/GSYiH & -3.245520 & 0.0829 & -7.836376 & 0.0000 \\
\hline Reel Efektif Döviz Kuru & -2.976659 & 0.1451 & -7.007324 & 0.0000 \\
\hline Sermaye Yeterlilik Rasyosu & -2.336794 & 0.4096 & -7.143571 & 0.0000 \\
\hline BIST 30 değeri & -2.934341 & 0.1574 & -8.939629 & 0.0000 \\
\hline Takipteki Krediler/Toplam Krediler & -3.690235 & 0.2850 & -7.359395 & 0.0000 \\
\hline
\end{tabular}


Engle-Granger Koentegrasyon Tekniği ile, seriler arasında uzun dönemli ilișkinin varlığı tespit edilmeye çalıșılmaktadır. Bunna göre, TR 5 yıllık CDS primleri ile büyüme oranı, ișsizlik oranı, TÜFE oranı ve cari açık/GSYiH oranı arasında uzun dönemli bir ilișki tespit edilememiștir. I(1) düzeyinde durağan olan diğer değișkenlerle model olușturularak değișkenler arasında koentegrasyonun varlığının tespit edilebilmesinin ikinci koșulu, kalıntı serilerinin durağanlık arz etmesidir. Bu amaçla, kalıntı serilerine Dickey Fuller Testi uygulanarak durağan olup olmadığı araștırılmakta ve serilerin durağan olması durumunda, değișkenlerin uzun dönemde birlikte hareket ettikleri anlașılmaktadır. Kalıntı serilerine ait birimkök test sonuçları așağıdaki tabloda yer almaktadır.

Tablo 2: Kalıntı Serileri için Birim-Kök (DF) Testi Sonuçları

\begin{tabular}{|l|c|c|}
\hline Bağımsız Değișkenlere Ait Seriler & t-istatistiği & Olasılık \\
\hline Reel Efektif Döviz Kuru, Kalıntı Serisi 1 & -11.94023 & 0.0000 \\
\hline Sermaye Yeterlilik Rasyosu, Kalıntı Serisi 2 & -11.18725 & 0.0000 \\
\hline BIST 30, Kalıntı Serisi 3 & -14.53920 & 0.0000 \\
\hline Takipteki Krediler/Toplam Krediler, Kalıntı Serisi 4 & -10.19843 & 0.0000 \\
\hline
\end{tabular}

Yukarıdaki tablo incelendiğinde, TR 5 yıllık CDS primleri ile reel efektif döviz kuru, sermaye yeterlilik rasyosu, BIST 30 değerleri ve takipteki krediler/toplam krediler oranı arasında uzun dönemli ilișki olduğu anlașılmaktadır. İzleyen așamada, serilerin orijinal hallerine Johansen Eșbütünleșme (Koentegrasyon) Tekniği uygulanarak, koentegrasyon ilișkisi tespit edilmeye çalıșılmaktadır. Așağıda görüleceği üzere, CDS primleri, reel efektif döviz kuru, bankacılık sektörü sermaye yeterliliği, takipteki krediler/toplam krediler ve BIST 30 değerleri arasında koentegrasyon ilișkisi yani eșbütünleșme bulunmaktadır. 
Tablo 3: Johansen Eșbütünleșme Testi Sonuçları

\begin{tabular}{|c|c|c|c|c|c|c|c|}
\hline \multicolumn{5}{|l|}{ İz İstatistiği } & \multicolumn{3}{|c|}{ Maksimum Özdeğer İstatistiği } \\
\hline $\begin{array}{l}\text { Eigen } \\
\text { Değer }\end{array}$ & & İz İstatistiği & $\begin{array}{c}\% 5 \\
\text { Kritik } \\
\text { Değer }\end{array}$ & Olasilık & $\begin{array}{l}\text { Maks.Eigen } \\
\text { Değer }\end{array}$ & $\begin{array}{c}\text { \%5 } \\
\text { Kritik } \\
\text { Değer }\end{array}$ & Olasilık \\
\hline 0.389356 & Yok* & 118.0412 & 88,8038 & 0.0001 & 39,9525 & 38.33101 & 0.032 \\
\hline 0.332544 & En Fazla $1^{*}$ & 78.08867 & 63,8761 & 0.0020 & 32,74685 & 32.11832 & 0.042 \\
\hline 0.233683 & En Fazla 2* & 45.34182 & 42,91525 & 0.0280 & 21,55895 & 25.82321 & 0.166 \\
\hline 0.174538 & En Fazla 3 & 23.78287 & 25,87211 & 0.0890 & 15,53674 & 19.38704 & 0.166 \\
\hline 0.096793 & En Fazla 4 & 8.246126 & 12,51798 & 0.2322 & 8,246126 & 12.51798 & 0.232 \\
\hline
\end{tabular}

Not: (*) \%5 düzeyinde anlamlılığı göstermektedir.

\section{Sonuç}

CDS primlerindeki değișimler, ülke ekonomik performansına ilișkin hem reel durumu hem de beklentileri yansıtmakta, dolayısıyla ülke kredi riskinin değerlendirilmesinde uluslararası yatırımcılar tarafından büyük ölçüde dikkate alınmaktadır. Finansal stresin yüksek olduğu ve kredi piyasalarında dalgalanmanın arttığı dönemlerde, ülkeye ilișkin makroekonomik ve finansal değișkenler ile CDS primleri arasındaki ilișkinin belirgin hale geleceği düșünülmektedir. Dolayısıyla, piyasada ișlem gören ülke CDS'lerine bakılarak ülkenin kredi riski ile ilgili öngörü yapmak mümkün hale gelmekte ve CDS primlerini analiz ederek, hem yatırımcılar hem politika yapıcıları uygun aksiyonlar alabilmektedir.

2010-2016 periyodunu kapsayan yukarıdaki çalıșmada, Türkiye 5 yıllık CDS primleri ile büyüme, enflasyon, ișsizlik, cari açık gibi makroekonomik göstergelerin arasındaki ilișkinin zayıf olduğu, söz konusu değișkenlerin açıklayıcı gücünün belirgin olmadığı sonucuna ulașılmıștır. Diğer yandan, Engle-Granger Koentegresyon Testi sonuçlarına göre, bağımlı değișken ve bağımsız değișkenler arasındaki ilișkiler sırasıyla analiz edildiğinde, reel efektif döviz kuru ile bankacılık sektörü sermaye yeterliliği, takipteki krediler/toplam krediler ve BIST 30 değerleri gibi finansal indikatörler ve CDS primleri arasında uzun dönemli ilișkiler tespit edilmiștir. Söz konusu değișkenlerin hep birlikte analize dahil edilmesiyle yapılan Johansen Koentegresyon Testinde, değișkenler arasındaki koentegrasyonun yüksek çıkması, sermaye yeterliliği 
ve takipteki kredilerdeki değișimler ve aynı zamanda, BIST 30'da yer alan hisse senetlerinin önemli kısmının bankacılık sektörüne ait olduğu göz önüne alındığında, BIST 30'daki değișimler ile CDS primleri arasında uzun dönemli bir ilișki olduğunu göstermektedir ve dolayısıyla, Türkiye CDS primlerindeki değișimde özellikle bankacılık sektörü performansının önemli bir rol üstlendiğine ișaret etmektedir. Son olarak, reel efektif döviz kuru ile CDS primleri arasında da uzun dönemli ilișkinin varlığı tespit edilmiștir.

\section{KAYNAKLAR}

Adam, M. 2013. Spillovers and Contagion in the Sovereign CDS market, Bank i Kredyt, 44 (6), Pages 571-604.

Akkaya, M. 2017. Türk Tahvillerinin CDS Primlerini Ełkileyen İçsel Faktörlerin Analizi, Maliye Finans Yazıları, Nisan 2017, 107, s. 130-145.

Beers, D. T. and M. Cavanaugh. 2008. Sovereign Credit Ratings: A Primer, Standard \&Poor's, New York.

Brandorf, C. ve J. Holmberg. 2010. Determinants of Sovereign Credit Default Swap Spreads for PIIGS- A Macroeconomic Approach, Bachelor Thesis, Lund Uniiversity School of Economics and Management.

Collin-Dufresne, P., R. S. Goldstein, and J. S. Martin. 2001. The Determinants of Credit Spread Changes, Journal of Finance 56, 2177-2207.

Cossin, D. ve G. Jung. 2005. Do Major Financial Crises Provide İnformation On Sovereign Risk to The Rest of The World? A Look at Credit Default Swap Markets, International Center for Financial Asset Management and Engineering, 134, ss. 1-31.

Fontana, A. and M. Scheicher. 2010. An Analysis of Euro Area Sovereign CDS, European Central Bank Working Paper Series 1271.

Gonzalo C.-M., K. Kostrzewa, A. Marszal and D. Serwa. 2016. Pricing Sovereign Credit Risk of an Emerging Market, ECB Working Paper Series, No: 1924, June 2016

Hull, J., M. Predescu and A. White. 2004. The Relationship between Credit Default Swap Spreads, Bond Yields, and Credit Rating Announcements, Journal of Banking and Finance 28, 2789-2811.

Hull, J. 2008. Options, Futures and Other Derivatives, 7th edition, Prentice Hall, New Jersey. 
Ismailescu, I. and H. Kazemi. 2010. The Reaction of Emerging Market Credit Default Swap Spreads to Sovereign Credit Rating Changes, Journal of Banking and Finance, 34(12), 2861 -2873.

Kliber, A. 2011. Sovereign CDS Instruments in Central Europe-Linkages and Interdependence, Dynamic Econometric Models, 11, 111-128.

Kisgergely, K. 2009. What Moved Sovereign CDS Spreads in the Period of Financial Turbulence?, Report on Financial Stability, November 2009, Central Bank of Hungary.

Koy, A. 2015. Kredi Temerrüt Swapları ve Tahvil Primleri Üzerine Ampirik Bir Calıșma, International Review of Economics and Management 2 (2015): 63-79

Longstaff, F. A., J. Pan, L. H. Pedersen and K. J. Singleton. 2011 . How Sovereign Is Sovereign Credit Risk?, American Economic Journal, 3(2), ss.75-103.

O'Kane, D. and S. Turnbull. 2003. Valuation of credit default swaps. Lehman Brothers Quantitative Credit Research Quarterly, 2003-Q1-Q2.

O'Kane, D. and S. Sen. 2004. Credit Spreads Explained. QCR Quarterly, vol. 2004-Q1/Q2, Lehman Brothers (March 2004).

Pan, J., and K.J. Singleton. 2008. Default and Recovery Implicit in the Term Structure of Sovereign CDS Spreads. The Journal of Finance, vol. 63, no. 5 (October 2008): 2345-2384.

Plank, T. J. 2010. Do Macro-Economic Fundamentals Price Emerging Market Sovereign CDS Spreads?, No: 10-5

Remolona, E. M., M. Scatigna and E. Wu. 2008. The Dynamic Pricing of Sovereign Risk in Emerging Markets: Fundamentals and Risk Aversion, The Journal of Fixed Income, 17(4), ss.57-71.

Sand, H.J. 2012. The Impact of Macro-Economic Variables On The Sovereign CDS Spreads of The Eurozone Countries, Master's Thesis, University of Groningen.

Tang, D.Y. and H. Yan. 2007. Liquidity and credit default swap spreads, Working paper, Kennesaw State University and University of South Carolina.

Tang, D.Y. and H. Yan. 2009. Market Conditions, Default Risk and Credit Spreads. Journal of Banking \& Finance, 34 (2010): 743-753.

Wallison, P. 2009. Everything You Wanted to Know About Credit Default Swaps: But Were Never Told. The Journal of Structured Finance, 15 (2), 20-30. 
